\title{
Correction to: Effects of cognitive rehabilitation in Parkinson disease: a metaanalysis
}

\author{
Andreina Giustiniani $^{1}{ }^{10} \cdot$ Lorenza Maistrello $^{1} \cdot$ Laura Danesin $^{1} \cdot$ Elena Rigon $^{1} \cdot$ Francesca Burgio $^{1}$ \\ Published online: 18 February 2022 \\ (c) Fondazione Società Italiana di Neurologia 2022
}

Correction to: Neurological Sciences (2022)

https://doi.org/10.1007/s10072-021-05772-4

The original published online version contains an error. An entire paragraph is missing in the manuscript, that is, "Included studies: main characteristics" in the Results section. The references citation is also missing, thus, list of the references are now updated.

The original article has been corrected.

Publisher's note Springer Nature remains neutral with regard to jurisdictional claims in published maps and institutional affiliations.

The original article can be found online at https://doi.org/10.1007/ s10072-021-05772-4

Andreina Giustiniani

andreina.giustiniani@hsancamillo.it

1 Neuropsychology Department, IRCCS San Camillo

Hospital, via Alberoni 70, 30126 Venice, Italy 